DOI: https://doi.org/10.32838/2523-4803/70-3-24

УДК 331.5.024.5

\title{
Жосан Г.В.
}

кандидат економічних наук, доцент, доцент кафедри менеджменту організацій, ДВНЗ «Херсонський державний аграрний університет»

\section{Zhosan Hanna}

Kherson State Agrarian University

\section{ОСОБЛИВОСТІ ВЗАЄМОДІЇ ГРУП СТЕЙКХОЛДЕРІВ МОЛОДІЖНОГО ПІДПРИЕМНИЦТВА}

\begin{abstract}
У статті на основі методу Інтернет-аналізу здійснено прогнозування попиту на вивчення розвитку поняття «молодіжне підприємництво». Встановлено, що за останні 11 років популярність даного поняття зросла, ие свідчить про позитивну тенденцію зростання інтересу у наукових колах, актуальність вибраного напряму для подальшого дослідження. Виділено чотири групи стейкхолдерів молодіжного підприємництва: держава, соиіальне середовище, освітнє середовище та бізнессередовище. Групи стейкхолдерів молодіжного підприємництва виділено автором відповідно до етапів його розвитку на мікрорівні (учнівський, інноваційно орієнтований, розвиток підприємницького потенціалу). Відповідно до даних етапів, представлено пріоритетні інтереси в розвитку молодіжного підприємництва кожної групи стейкхолдерів, а також вектори їхніх інтересів у рамках роботи з молодими підприємиями.
\end{abstract}

Ключові слова: молодіжне підприємництво, стейкхолдери, пріоритетні інтереси, вектор інтересів.

Постановка проблеми. Посилення ролі молодіжного підприємництва сьогодні одним із пріоритетних напрямів розвитку економіки України. Молодіжний бізнес є більш адаптивним, швидше реагує на зміни динамічного зовнішнього середовища та його виклики та загрози, активно сприяє розвитку інноваційного потенціалу економіки, здійсненню комерціалізації наукових досліджень і впровадженню інноваційних технологій. Молодь є найактивнішою і креативною частиною суспільства, здатною з найбільшою віддачею брати участь в економічному житті країни і регіону, 3 легкістю сприймати все нове і з більшим ступенем готовності брати на себе ризики. У сучасних умовах ключова парадигма інноваційних економік - S2B (Science to business - «наука - бізнес») стала головним імпульсом економічного розвитку, що актуалізує необхідність глибокого розгляду чинників розвитку молодіжного підприємництва і вдосконалення системи його підтримки освітнім середовищем, бізнес-середовищем, соціальним середовищем та державою.

Аналіз останніх досліджень і публікацій. Дослідження стану розвитку молодіжного підприємництва представлено в роботах Л. Бокова, О. Дьяченко, С. Карева, А. Кобзєва, Л. Копєйкіної, С. Кортова, А. Куликова, Г. Лаптєва, С. Лендера, О. Молчанової, А. Мокроносова, І. Мошкина, Н. Судакової, Г. Широкова, Д. Шульгіна та ін. Однак у сучасних дослідженнях недостатньо вивчено особливості створення та розвитку молодіжного підприємництва, що зумовило вибір теми дослідження.
Формулювання цілей статті. Мета роботи визначити групи стейкхолдерів молодіжного підприємництва, їх учасників та виділити інтереси кожної групи стейкхолдерів під час взаємодії між собою та 3 молодими підприємцями.

Виклад основного матеріалу. Інтеграція освіти, науки і бізнесу, головним чином, сприяє науково-технічному прогресу, а стійкі взаємозв'язки малого, середнього і великого бізнесу є основою розвитку країни і підвищення конкурентоспроможності іiі економіки. Зазначені тенденції актуалізують проблему розвитку молодіжного підприємництва та взаємодії з освітнім середовищем, бізнес-середовищем, соціальним середовищем та державою як джерелами його ефективного функціонування в економіці регіону.

Нині розвиток молодіжного підприємництва в Україні тільки починається. Лише недавно вітчизняні вчені почали приділяти увагу процесу формування молодіжного підприємництва, а опису дієвих механізмів і методик його розвитку практично немає. Недостатньо уваги приділено вивченню всього комплексу чинників, у тому числі особистісних, підвищення ефективності функціонування малих підприємств.

Популяризацію поняття «молодіжне підприємництво» пропонуємо довести за допомогою методу Інтернет-аналізу [1]. Це поняття становить так званий категоріальний апарат галузі наукових досліджень. Отже, вхідними даними є:

1. Множина $T=\left\{t_{j}\right\}$, дефініції: молодіжне підприємництво. 
2. Період дослідження: 2010-2020 роки - множина $\mathrm{G}=\left\{\mathrm{g}_{\mathrm{k}}\right\}, \mathrm{k}=1 \div 11$.

3. Множина пошукових серверів, 3 яких проводиться усереднення даних: Google, Yandex, Yahoo, I.UA, Mail, Alltheweb, Rambler, Bing, Meta, Nigma, Metabot, AltaVista, Wikipedia, UaPORT, Uaportal, Holms, Poshuk, Weblist, List, Lycos, UP, Infoseek, Magellan, Galaxy, Webcrawler, Dmoz, Jayde, Asiannet, REX, Euroseek, Search.MSN, Whatuseek.

У даному дослідженні визначено питому вагу посилань в Інтернеті на дефініцію «молодіжне підприємництво» за 2010-2020 рр. (рис. 1). Дані отримано експериментальним шляхом, які нормалізовано для кращої візуалізації і можливості порівняння між собою.

Побудовано прогноз популярності дефініції «молодіжне підприємництво» у 2021 р. (рис. 1). Під час побудови трендової моделі у програмі Excel особливе значення має вибір типу кривої. Нерідко один і той самий часовий ряд достатньо добре описується декількома функціями. Аналіз лінії тренду показав, що змінення питомої ваги посилань на дефініцію «молодіжне підприємництво» найкраще апроксимує поліном 5-го ступеня. Збільшення його ступеню вище 5-го не дає помітного поліпшення моделі.

Щільність розподілу посилань на дефініцію «молодіжне підприємництво» має загальну позитивну тенденцію впродовж періоду з досить великою точністю апроксимації $(>0,7)$, що підтверджує достовірний прогноз подальшого підвищення популярності молодіжного підприємництва і свідчить про доцільність нових досліджень у цій сфері. У 2021 р. передбачається збільшення питомої ваги посилань в Інтернеті до $30 \%$.

На рис. 1 для кожного року наведено межі стандартної помилки, які визначають точність виміру. Через інерційність даних похибка знаходиться у межах попереднього і наступного років.

Актуальність методу Інтернет-аналізу зумовлюється тим, що сучасна хвиля комп'ютерно-інформаційного прогресу трансформує суспільство та формує Інтернет-покоління. Цей метод допомагає висвітити невідкладність вирішення будь-якого питання.

Стосовно даного дослідження на основі методу Інтернет-аналізу здійснено прогнозування попиту на вивчення розвитку поняття «молодіжне підприємництво». Отже, за проведеним дослідженням можна зробити висновок, що за останні 11 років популярність даного поняття зросла, проте стабільне підвищення його популярності почалося тільки з 2013 р. (рис. 1), що зумовлено відповідними політико-економічними подіями в країні. Це свідчить про позитивну тенденцію, зростання інтересу у наукових колах, актуальність вибраного напряму для подальшого дослідження.

Молодіжне підприємництво - один із найбільш перспективних напрямів розвитку економіки країни, що $€$ фактично потенціалом iї зростання. Сьогодні його роль і значення активно обговорюються як в урядових, так і в підприємницьких та наукових колах. На думку автора, застосування теорії зацікавлених сторін і виділення основних учасників та їхніх пріоритетних інтересів можуть сприяти підвищенню ефективності розвитку досліджуваного напряму. Використання даної концепції буде стимулювати і зацікавлювати в розвитку молодіжного підприємництва представників освітнього середовища, бізнес-середовища, соціального середовища та держави. У рамках дослідження аргументується положення, що саме спільні дії представлених груп стейкхолдерів можуть підвищити підприємницьку активність у молодіжному середовищі.

У сучасному світі досить непросто визначитися 3 родом і видом діяльності. Сьогодні багато молодих людей замислюються відкрити свій бізнес, зайнятися підприємництвом, але не всі вирішуються на це. Грунтуючись на аналізі різних джерел, підприємництво можна охарактеризувати як ризикову економічну діяльність, спрямовану на систематичне отримання прибутку від

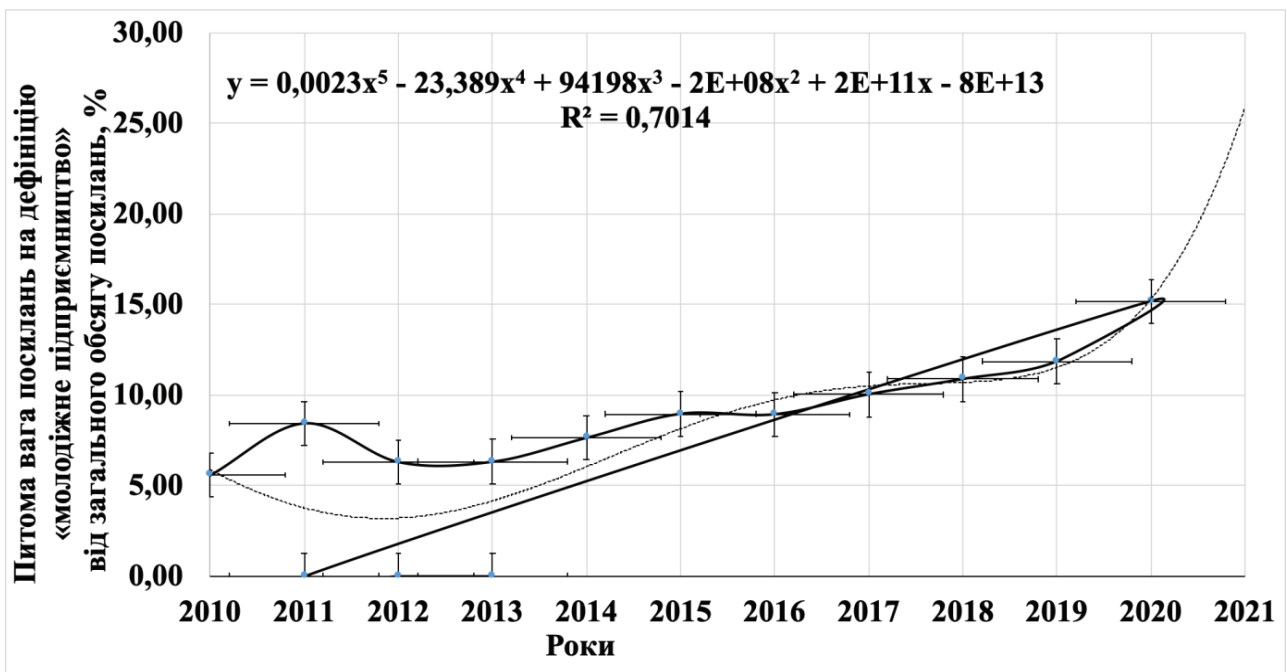

Рис. 1. Прогноз питомої ваги посилань

на дефініцію «молодіжне підприсмництво» (поліном 5-го ступеня), \%

Джерело: розраховано автором 
виробництва і продажу товарів, надання послуг, виконання робіт. Молоді люди креативно мислять, амбітні і готові змінювати світ, ризикувати, а не тільки отримувати прибуток. Дана соціальна група - найактивніша частина суспільства, яка швидко реагує на будь-які зміни в житті й ефективно сприймає позитивні його боки.

Автором виділено чотири групи стейкхолдерів молодіжного підприємництва: держава, соціальне середовище, освітнє середовище та бізнес-середовище. Кожна з виділених груп включає у себе декілька учасників (рис. 2) [2]. Соціальне середовище включає населення, громадські організації, студентство; група «держава» - органи державної влади та органи місцевого самоврядування; освітнє середовище - заклади освіти та інституції неформальної освіти, бізнес-середовище включає у себе бізнес-асоціації та бізнес-структури.
Кожна з груп стейкхолдерів має певні пріоритетні інтереси в декількох напрямах - взаємодія між собою під час роботи з молодими підприємцями та напряму 3 молодими підприємцями.

У табл. 1 автором представлено пріоритетні інтереси в розвитку молодіжного підприємництва кожної групи стейкхолдерів відповідно до етапів розвитку молодіжного підприємництва: учнівського етапу, інноваційно орієнтованого етапу та етапу розвитку підприємницького потенціалу [2].

Водночас взаємодія груп стейкхолдерів між собою в рамках роботи з молодими підприємцями передбачає їх вектори інтересів (табл. 2).

Узагальнюючи вищевикладене, необхідно зазначити, що для вирішення проблем молодіжного підприємництва держава повинна залучати інститути

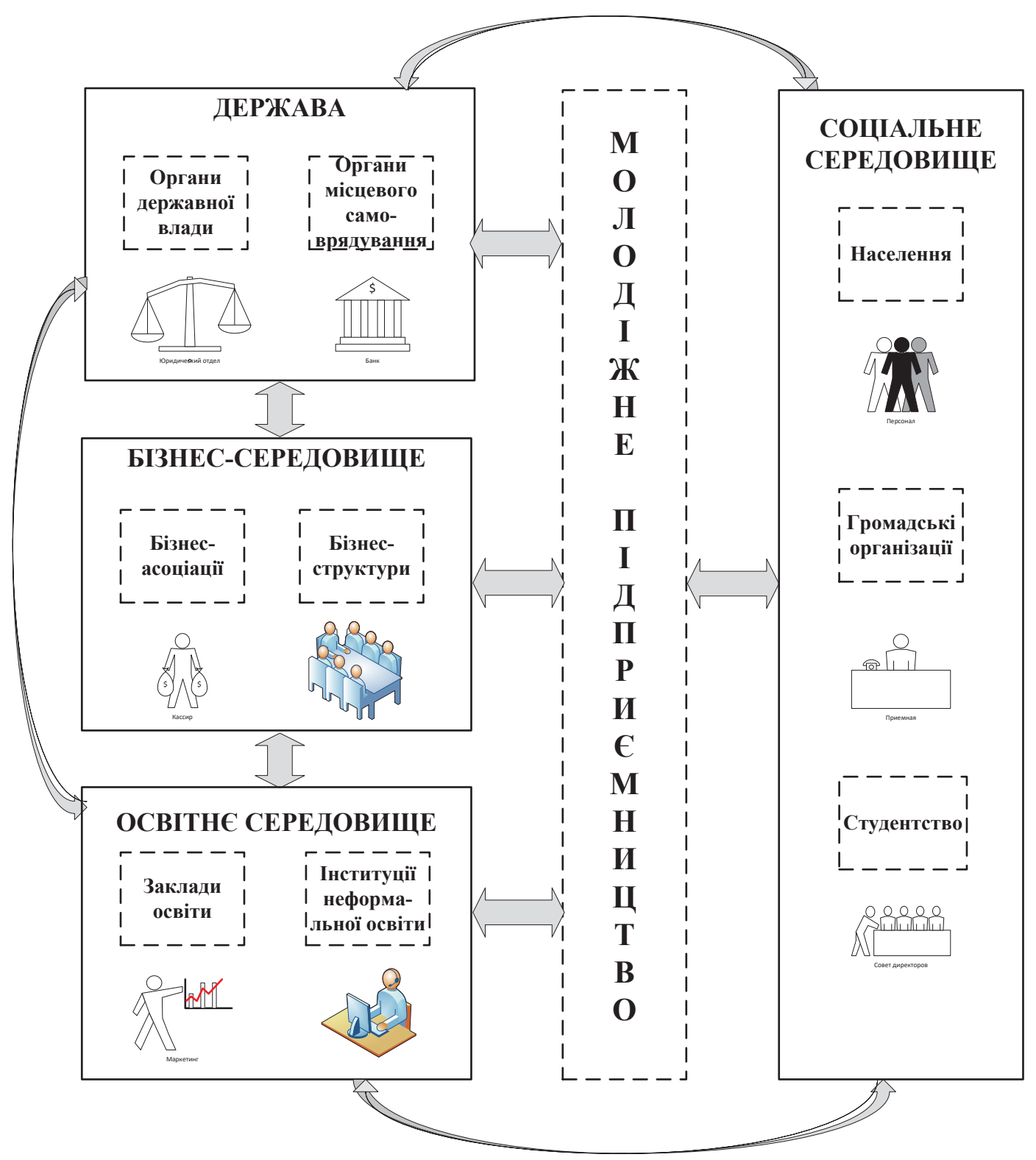

Рис. 2. Схема взаємодії стейкхолдерів молодіжного підприємництва 
Пріоритетні інтереси стейкхолдерів за етапами розвитку молодіжного підприємництва

\begin{tabular}{|c|c|c|c|}
\hline \multirow{2}{*}{$\begin{array}{c}\text { Групи стейкхолдерів } \\
\text { молодіжного } \\
\text { підприсмництва }\end{array}$} & \multicolumn{3}{|c|}{ Етапи розвитку молодіжного підприсмництва } \\
\hline & І. Учнівський & $\begin{array}{c}\text { II. Інноваційно } \\
\text { оріснтований }\end{array}$ & $\begin{array}{c}\text { III. Розвиток підприємницького } \\
\text { потенціалу }\end{array}$ \\
\hline Освітнє середовище & $\begin{array}{l}\text { 1. Підвищення ефективності } \\
\text { взаємодії з представниками } \\
\text { бізнес-середовища }\end{array}$ & $\begin{array}{c}\text { 1. Оновлення матеріальної } \\
\text { бази (створення бізнес- } \\
\text { хабів, бізнес-інкубаторів } \\
\text { тощо) }\end{array}$ & $\begin{array}{c}\text { 1. Підвищення } \\
\text { конкурентоспроможності на ринку } \\
\text { освітніх послуг }\end{array}$ \\
\hline Бізнес-середовище & $\begin{array}{l}\text { 1. Наставництво } \\
\text { 2. Розширення підприємницького } \\
\text { світогляду }\end{array}$ & $\begin{array}{l}\text { 1. Розширення масштабів } \\
\text { діяльності }\end{array}$ & $\begin{array}{l}\text { 1. Максимізація прибутку } \\
\text { 2. Збільшення інвестування }\end{array}$ \\
\hline Соціальне середовище & $\begin{array}{c}\text { 1. Підвищення кваліфікації } \\
\text { 2. Можливість спробувати себе } \\
\text { в бізнесі }\end{array}$ & $\begin{array}{l}\text { 1. Збільшення кількості } \\
\text { товарів та послуг } 3 \\
\text { розвитком бізнесу }\end{array}$ & $\begin{array}{c}\text { 1. Створення нових робочих місць } \\
\text { 2. Підвищення кваліфікації } \\
\text { благодійництво }\end{array}$ \\
\hline Держава & $\begin{array}{c}\text { 1. Працевлаштування студентів } \\
\text { та випускників вузів } \\
\text { 2. Підвищення зайнятості молоді }\end{array}$ & $\begin{array}{c}\text { 1. Розвиток економіки } \\
\text { за рахунок молодіжного } \\
\text { підприємництва }\end{array}$ & 1. Поповнення бюджету \\
\hline
\end{tabular}

Джерело: розробка автора

Таблиця 2

Вектори інтересів груп стейкхолдерів у рамках роботи з молодими підприсмцями

\begin{tabular}{|c|c|c|c|c|}
\hline & Освітнс середовище & Бізнес-середовище & $\begin{array}{c}\text { Соціальне } \\
\text { середовище }\end{array}$ & Держава \\
\hline $\begin{array}{c}\text { Освітнє } \\
\text { середовище }\end{array}$ & - & $\begin{array}{l}\text { Підвищення ефективності } \\
\text { взаємодії з бізнес- } \\
\text { спільнотами }\end{array}$ & $\begin{array}{l}\text { Сприяння } \\
\text { підвищенню якості } \\
\text { освіти } \\
\end{array}$ & $\begin{array}{l}\text { Підвищення } \\
\text { конкурентоспроможності ринку } \\
\text { освітніх послуг }\end{array}$ \\
\hline $\begin{array}{c}\text { Бізнес- } \\
\text { середовище }\end{array}$ & $\begin{array}{l}\text { Дуальна освіта, } \\
\text { можливість вибрати } \\
\text { для працевлаштування } \\
\text { молодих фахівців }\end{array}$ & 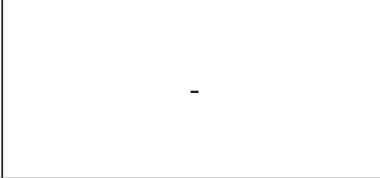 & \begin{tabular}{|l} 
Взаємодія через \\
інших стейкхолдерів
\end{tabular} & $\begin{array}{l}\text { Забезпечення зайнятості } \\
\text { місцевого населення, } \\
\text { досягнення стратегічних цілей і } \\
\text { завдань, зростання надходжень } \\
\text { до бюджету }\end{array}$ \\
\hline $\begin{array}{l}\text { Соціальне } \\
\text { середовище }\end{array}$ & $\begin{array}{l}\text { Можливість отримати } \\
\text { практично орієнтованні } \\
\text { знання, дуальна } \\
\text { освіта, підвищення } \\
\text { кваліфікації тощо } \\
\end{array}$ & $\begin{array}{l}\text { Взаємодія через інших } \\
\text { стейкхолдерів }\end{array}$ & - & $\begin{array}{l}\text { Сприяє формуванню } \\
\text { сприятливого клімату, } \\
\text { збільшенню чисельності людей, } \\
\text { залучених у трудову діяльність }\end{array}$ \\
\hline Держава & $\begin{array}{l}\text { Поліпшення якості } \\
\text { освітніх послуг }\end{array}$ & $\begin{array}{l}\text { Зниження } \\
\text { адміністративних бар'єрів } \\
\text { Підвищення рівня } \\
\text { фінансування програм } \\
\text { підтримки підприємництва } \\
\text { Створення об'єднань } \\
\text { підприємців }\end{array}$ & $\begin{array}{l}\text { Забезпечення } \\
\text { соціальної } \\
\text { стабільності, } \\
\text { сприятливі умови } \\
\text { життя, зайнятість } \\
\text { населення }\end{array}$ & - \\
\hline
\end{tabular}

Джерело: розробка автора

громадянського суспільства, громадські та некомерційні організації, самих підприємців. При цьому важливо розуміти, що молодь повинна бути безпосереднім учасником вирішення регіональних проблем і не має знаходитися виключно в ролі об'єкта виховання, навчання і соціалізації. Дані заходи, на думку автора, будуть сприяти розвитку молодіжного підприємництва, створюючи комфортні умови для цього; держава ж, своєю чергою, може ініціювати масове залучення молодих людей до підприємницької діяльності.

Висновки. Таким чином, інтенсивний розвиток молодіжного підприємництва, особливо його інноваційного типу, є ключовою детермінантою модернізації національної економіки та інвестиційно-інноваційної мультиплікації іiі зростання. Молодіжне підприємництво (завдяки соціально-психологічним особливостям молоді як найбільш активної, креативної частини суспільства) є гнучкішим і чутливішим до змін зовнішнього середовища, що сприяє розвитку і реалізації інноваційного потенціалу економіки, комерціалізації інновацій і впровадження інноваційних технологій. Для успішного розвитку молодіжного підприємництва регіону необхідні посилення та перманентна координація узгодженості інтересів стейкходерів: представників бізнес-середовища, держави, освітнього середовища та соціального середовища, що дає змогу у безконфліктній формі досягати поставлених цілей усіма суб'єктами молодіжного підприємництва.

У подальших дослідженнях доцільно провести анкетування представників кожної з груп стейкхолдерів та визначити ключові показники розрахунку ефективності молодіжного підприємництва регіону. 
Список літератури:

1. Жосан Г.В. Соціальна відповідальність у забезпеченні результативності діяльності підприємства : автореферат дис. ... канд. екон. наук. Херсон, 2014. 20 с.

2. Жосан Г.В. Визначення стейкхолдерів молодіжного підприємництва. Integración de las ciencias fundamentales y aplicadas en el paradigma de la sociedad post-industrial : Colección de documentos científicos « $\Lambda$ 'ОГО $»$ con actas de la Conferencia Internacional Científica y Práctica (Vol. 1), 24 de abril de 2020. Barcelona, España: Plataforma Europea de la Ciencia. P. 48-52. URL : https://ojs.ukrlogos.in.ua/index.php/logos/issue/view/24.04.2020/280b46a02c5a782\&title=Statistic hniTaInformatsiiniMaterialiSchodoStanuTaRozvitkuMalogoISerednogoPidprimnitstva (дата звернення: 30.04.2020).

3. Опфер Е.А. Мониторинг удовлетворенности заинтересованных сторон вуза качеством образования. PrimoAspectu. 2014. T. 16. № 5(132). C. 135-138.

\section{References:}

1. Zhosan G.V. (2014) Sotsialna vidpovidalnist u zabezpechenni rezultatyvnosti diialnosti pidpryiemstva [Social responsibility in ensuring the performance of the enterprise] (PhD Thesis), Kherson: Kherson National Technical University.

2. Zhosan G.V. (2020) Vyznachennia steikkholderiv molodizhnoho pidpryiemnytstva [Determination of Stakeholders of Youth Entrepreneurship] Integración de las ciencias fundamentales y aplicadas en el paradigma de post-industrial: Colección de documentos cientificos «OGO » con actas de la Conferencia Internacional Cientifica y Práctica 1), 24 de abril de 2020. Barcelona, España: Europea de la Ciencia platform, pp. 48-52. Available at: https://ojs.ukrlogos.in.ua/index.php/ logos/issue/view/24.04.2020/280b46a02c5a782\&title=StatistichniTaInformatsiniMaterialiSchodoStanuTaRozvitkuMalogo ISerednogoPidprimnitstva

3. Ofer E.A. (2014) Monytorynh udovletvorennosty zaynteresovannukh storon vuza kachestvom obrazovanyia [Monitoring stakeholder satisfaction with the quality of education]. PrimoAspect, tom. 16, vol. 5 (132), pp. 135-138.

\section{ОСОБЕННОСТИ ВЗАИМОДЕЙСТВИЯ ГРУПП СТЕЙКХОЛДЕРОВ МОЛОДЕЖНОГО ПРЕДПРИНИМАТЕЛЬСТВА}

В статье на основе метода Интернет-анализа осуществлено прогнозирование спроса на изучение развития понятия «молодежное предпринимательство». Установлено, что за последние 11 лет популярность данного понятия выросла, это свидетельствует о положительной тенденции, росте интереса в научных кругах, актуальности выбранного направления для дальнейшего исследования. Автором выделены четыре группы стейкхолдеров молодежного предпринимательства: государство, сочиальная среда, образовательная среда и бизнес-среда. Группьл стейкхолдеров молодежного предпринимательства выделены в соответствии с этапами его развития на микроуровне (ученический, инновационно ориентированный, развитие предпринимательского потенциала). Согласно данным этапам, представлены приоритетные интересы в развитии молодежного предпринимательства каждой группы стейкхолдеров, а также векторы их интересов в рамках работы с молодыми предпринимателями.

Ключевые слова: молодежное предпринимательство, стейкхолдеры, приоритетные интересы, вектор интересов.

\section{FEATURES OF INTERACTION OF GROUPS OF YOUTH ENTREPRENEURS 'GROUPS}

The purpose of the article is to identify stakeholder groups of youth entrepreneurship, their participants and to highlight the interests of each stakeholder group in interaction with each other and with young entrepreneurs. In the article, based on the method of Internet analysis, the demand for studying the development of the concept of "youth entrepreneurship" is made. It is established that over the past 11 years the popularity of this concept has increased - this indicates a positive trend, growing interest in academia, the relevance of the chosen direction for further research. The author identifies four groups of youth entrepreneurship stakeholders: the state, the social environment, the educational environment and the business environment. Stakeholder groups of youth entrepreneurship are selected by the author according to the stages of its development at the micro level (I. Student, II. Innovation-oriented, III. Development of entrepreneurial potential), each of which is characterized by specific features of business behavior of young entrepreneurs, as well as the results, moving to the next level. According to these stages, the author presents priority interests in the development of youth entrepreneurship of each stakeholder group, as well as vectors of their interests in the framework of working with young entrepreneurs. The first type of interaction is based on the interaction of major stakeholder groups and youth entrepreneurship. The state, by supporting youth entrepreneurship, can promote the development of infrastructure, create conditions for replenishment of the budget, organize centers for interaction with youth. The second type of stakeholder relationship is, for example, the process of interaction between the state and the business environment, which is expressed by entrepreneurs in securing employment for local people, achieving strategic goals and objectives, increasing budget revenues. The interaction of the business environment with youth entrepreneurship will increase revenues, expand the scope of activities, diversify and modernize production, increase investment, use modern technologies.

Key words: youth entrepreneurship, stakeholders, priority interests, vector of interests. 